\title{
COMMUNICATION AUDIT AND KNOWLEDGE MANAGEMENT AUDIT AS KINDS OF INTERNAL AUDITS IN THE MANAGEMENT OF INTANGIBLE ASSETS OF AN ORGANIZATION
}

\author{
Renata Winkler \\ Cracow University of Economics, Cracow, Poland \\ e-mail: winklerr@uek.krakow.pl \\ (C) 2018 Renata Winkler \\ This is an open access article distributed under the Creative Commons Attribution-NonCommercial-NoDerivs license \\ (http://creativecommons.org/licenses/by-nc-nd/3.0/) \\ DOI: $10.15611 / \mathrm{ms} .2018 .2 .05$ \\ JEL Classification: M42, O20, O34.
}

\begin{abstract}
Along with the development of the Internet and information technologies, broadening of the scope of intellectual property rights and occurrence of the intellectual leverage effect with regard to the use of knowledge in preparing innovative products and services, it is possible to observe a growth in the importance of intangible assets in building strategic advantage of business entities. Important is that effective organisation management requires skilful use of information reflecting functioning of all subsystems of a given institution, including the functional systems (such as communication system and knowledge management system classified as intangible assets). Such knowledge is provided by an internal audit being a tool including independent and objective analysis of efficacy and efficiency of processes, which is used first of all to facilitate these processes. The purpose of this study is thus to present the possibility of using the audit in business practice of intangible assets management with regard to communication system and knowledge management system.
\end{abstract}

Keywords: audit, intangible assets, communication, knowledge management.

\section{Introduction}

An organization's asset can be identified as everything which the organization knows or has and may use to prepare and implement a strategy enabling improvement in its financial performance [Rokita 2005, p. 139]. For obvious reasons, business entities are significantly differentiated in terms of possessed assets of both a material and intangible nature. The features (qualitative and quantitative) of particular assets (material and intangible) and their unique configuration within a given organization have significant importance for building the strategic advantage of business entities [Matejun, Motyka 2016, p. 37]. The set of areas counted to in intangible resources is difficult to consider to be unambiguously defined. The intangible resource group includes: competences (including knowledge, experience and abilities), organizational relationships (internal and external), functional systems (for example: recruitment, personnel policy, motivation, training, quality assurance, information, communication, knowledge management), as well as intellectual property rights e.g. patents, trade secrets, contracts and licenses, databases, information, organizational and personal contact networks, employee knowledge (and consultants / suppliers / distributors), employee attitudes and possibilities, company's reputation, product brand and organizational culture, also innovation, quality, customer relations, management skills, alliances, technologies, brand value and relations with employees [Mikuła, PietruszkaOrtyl 2010, p. 36-38; Pietruszka-Ortyl 2010, p. 54; Hall 1992, p. 140; Skorwon 2013, p. 154]. What is important, along with the development of the Internet and information technologies, broadening the scope of intellectual property rights and the occurrence of the intellectual leverage effect with regard to the use 
of knowledge in preparing innovative products and services, is that it is possible to observe a growth in the importance of intangible assets in this aspect [Głuszek 2004, p. 260].

At present, effective organization management requires the skillful use of information reflecting the functioning of all subsystems of a given institution, including the functional systems (such as the communication system and the knowledge management system, classified as intangible assets). Such knowledge is provided by an internal audit [Milewska-Zawada 2016, p. 252] being a tool including the independent and objective analysis of the efficacy and efficiency of processes, which is used first of all to facilitate these processes. The purpose of this study is thus to present the possibility of using the audit in the business practice of intangible assets management with regard to the communication system and knowledge management system.

\section{Communication audit: purposes, tools}

It is impossible to negate the fact that the quality and efficiency of information flow within an organization cannot be separated from the problems related to its operation. Communication is an integral aspect of the operation of each economic system. The more variable and consistent operation conditions of a given institution, the more fundamental significance (at the level of both operational, tactical and strategic) is given to access to proper information in the right time. Furthermore, an efficient and effective communication process contributes to the direct involvement of people in the organization in achieving its objectives, raises the effectiveness of the management system and enables the improvement of operation of the whole organization. The fact is also that many institutions are not aware of the communication system's importance and are dominated by the opinion that there is no need to sustain outlays on something which remains immeasurable in revenues [Wilczewski 2014, p. 99].

Communication quality and the effectiveness level in a company depends on its [Winkler 2015, p. 110]:

- structure (channels and means of communication used, "length" of the transfer path),

- organizational culture (procedures in place, imposed behaviours and language contents),

- communication assets owned by the institution (quantity and quality of transferred contents, their: suitability, relevance, validity, credibility, completeness etc.),

- people participating in the processes of communication (due to their communication skills).
Additionally, the specific character of the interpersonal communication process itself (with regard to preparing clear and fixed procedures) and the fact that in every organization in a vertical (vertical communication), horizontal(horizontalcommunication) and diagonal ("oblique" communication) system, two communication areas intermingle: formal (structured) and informal (unstructured) results in the fact that there is an objective difficulty in measuring and presenting the effects of communication.

A communication audit enables an objective review of the communication inside an organization. In professional literature the term "communication audit" has been in use since the 1950s [Shelby, Reinsch 1996, p. 97]. A communication audit's objectives are defined in a diverse manner. According to D. Quinn and O. Hargie [2004, p. 148], conducting an internal communication audit is, first of all, intended for the identification of:

- information gaps,

- improper effect of the informal communication networks,

- communication delays ("information failures"),

- problems in "bottom-up" communication,

- inappropriate communication channels,

- reasons for weakening of the impact of the senior management,

- reasons for low meeting effectiveness.

On the other hand, according to O. Hargie and

D. Tourish [2009, p. 31], a communication audit should facilitate the identification of:

- Who should communicate with whom within the organization?

- Who is currently communicating with whom?

- What problems are communicated?

- Where does the information come from?

- How do people receive information?

- How the communication affects the relations between the employees?

A communication audit's objectives are also determined as follows [Audyt... 2009, p. 4]:

- testing communication consistency of the organization,

- identification of communication barriers and gaps,

- testing the effectiveness of vertical and horizontal communication,

- measurement of satisfaction of employees with internal communication,

- identification of the roles of employees in the process of communication (for instance communication leaders or information brokers).

Much depends on the organization itself: its size, type, structure, and the level of the communication 
system development. For each particular organization it is necessary to design "a tailored" communication audit. This is conditioned mainly by the specific character of the interpersonal communication process itself, which not only cannot be quantified directly, but is also difficult to prepare clear and fixed procedures regarding it, even more so because the process of communication cannot be equated with the diagnosed flows of various types of messages and information within the organization. Although, as mentioned, the internal communication process is substantially determined by the organization system (within which it is implemented), the scope of the present and prospective communication needs of those employed in an organization does not depend solely on the scope of the tasks attributed to them.

It is worth mentioning that, regardless of definition of the main bundle of objectives, a communication audit enables dispelling many illusions, myths and false opinions which function with regard to the communication climate and organizational culture. Basically, this audit should facilitate [Tourish, Hargie 2000, p. 26]:

- a diagnosis of who communicates with whom,

- an identification of which objectives attract the most attention and communication energy and at the same time diagnosing which of the assumed objectives arouse the most concerns, and also determining how many messages related to primary objectives are received and sent within the community of employees,

- a diagnosis of the level of trust between the participants of information exchange within the organization,
- identifying the general quality of professional relations within the organization.

The basic research methods used in regard to the communication audit include survey questionnaire, interview, network analysis and focus group a communication audit can also use such tools as [Winkler 2010, pp. 122-124]:

- group interview,

- communication log,

- ECCO (Episodic Communication Channels in Organization Analysis),

- Mystery Shopper,

- video recording,

- critical events analysis,

- thick description,

- Delphi method,

- participating observation,

- complex inventory-taking of the information system (IKSI),

- matrix description,

- the KSS communication system analysis,

- analysis of the KIWA information values and communication,

- analysis of the length of the DZA information processes,

- functional analysis of the FAOR information system,

- analysis of information flow paths,

- analysis of information streams,

- analysis of the KSA communication structure.

The conclusions from the audit focused on the improvement in the internal communication process may apply to such problematic issues as [Wilczewski 2014, p. 106]:

Table 1. Proposed ranges of the communication audit checklist

\begin{tabular}{|c|c|c|c|c|}
\hline $\begin{array}{l}\text { Scope of communication } \\
\text { from the sender } \\
\text { of information }\end{array}$ & $\begin{array}{l}\text { The importance } \\
\text { of communication } \\
\text { in information policy }\end{array}$ & $\begin{array}{l}\text { Trust in communication } \\
\text { and quality of feedback }\end{array}$ & $\begin{array}{l}\text { Satisfaction of recipient } \\
\text { with communication }\end{array}$ & $\begin{array}{l}\text { Interference in the } \\
\text { communication } \\
\text { information channel }\end{array}$ \\
\hline $\begin{array}{l}\text { - the role of } \\
\text { communication at } \\
\text { work } \\
\text { - providing the } \\
\text { necessary information } \\
\text { - detail of the written } \\
\text { information } \\
\text { - understandability of } \\
\text { written information } \\
\text { - synthetism of the } \\
\text { transmitted information }\end{array}$ & $\begin{array}{l}\text { - delay in providing the } \\
\text { information } \\
\text { - receiving information } \\
\text { on demand } \\
\text { - the importance of } \\
\text { information in the } \\
\text { decision-making } \\
\text { process } \\
\text { - quality of information } \\
\text { in the work process } \\
\text { - reasons for receiving } \\
\text { information }\end{array}$ & $\begin{array}{l}\text { - the need to receive } \\
\text { information about the } \\
\text { results of work } \\
\text { - the possibility of } \\
\text { losing a position in } \\
\text { communication } \\
\text { - the impact of } \\
\text { information on } \\
\text { reputation } \\
\text { - no use of information } \\
\text { /omission/ } \\
\text { - the need to inform } \\
\text { about difficulties at } \\
\text { work }\end{array}$ & $\begin{array}{l}\text { - the need to receive } \\
\text { information } \\
\text { - the need to receive } \\
\text { full information } \\
\text { - unambiguity of } \\
\text { information } \\
\text { - satisfaction with the } \\
\text { substantive level of } \\
\text { information } \\
\text { - necessity of } \\
\text { information }\end{array}$ & $\begin{array}{l}\text { - receiving undistorted } \\
\text { information } \\
\text { - obtaining the most } \\
\text { important information } \\
\text { - level of information's } \\
\text { limitation due to } \\
\text { interference } \\
\text { - necessity of information } \\
\text { in conditions of } \\
\text { disturbances } \\
\text { - failure to obtain } \\
\text { information about work } \\
\text { due to disturbances }\end{array}$ \\
\hline
\end{tabular}

Source: [Grabosz 2014, pp. 48-50]. 
- supplementing knowledge about organizational structures, information concerning the scope of operations of different departments of the company and those crucial for the company's functioning and the internal communication;

- supplementing knowledge related to the existing communication strategy - in particular with regard to its weak points;

- development of knowledge concerning the correct use of the communication infrastructure, adequacy of selection of communication channels and their effectiveness;

- undertaking measures in order to overcome difficulties in communication between employees.

While the audit process of the internal communication system itself (since it should diagnose these communication aspects which may be supervised and which may have a substantial effect on the course of communication) should be referred to such aspects as [Grabosz 2014, p. 48]: senders, message, recipients, feedback, communication interferences, styles and satisfaction.

The proposed ranges of the communication audit checklist are presented in Table 1.

\section{Knowledge management audit}

Knowledge may be defined in many ways. It may be seen as information in action, information placed in a context, state of the mind, an item, a process. In the publications related to knowledge management it is defined as: intangible, elusive, simultaneously occurring, nonlinear, complex, non-exhaustive, and cumulative. Conventionally, it is divided into nonconfidential and confidential. Knowledge management is combined with the acquisition, gathering and use of knowledge so as to achieve competitive advantage and increase the value of the organization ${ }^{1}$. The aim is getting the right knowledge to the right people at the right time and making people share and use it in ways that will improve organizational performance. "Knowledge management" in one of the terms strictly related to intangible assets because skillful knowledge management is of critical importance for creating the most valuable intangible assets and the use of knowledge, in practice, implies the use of intangible assets to create value [Urbanek 2011, p. 18]. A knowledge management audit (defined also as a knowledge audit) consists in the analysis and evaluation of knowledge management in business processes by means of [Mertins, Heisig, Vorbeck 2013, p. 46]:

- diagnosis of the strengths and weaknesses of knowledge management implemented in the institution - with a particular focus on practices used in this respect,

- analysis of the circumstances, barriers and opportunities of knowledge management - also in the context of the existing institution culture, leadership and information technologies used,

- developing the awareness of the necessity of knowledge management in an institution,

- designing methods of measurement of knowledge management,

- collection of measurable data concerning benefits earned under the initiatives related to knowledge management.

A knowledge audit also means the evaluation of organizational knowledge from the point of view of its availability, usability and the possibility to achieve by it competitive advantage in an organization resulting from its use. In practice, the audit is both [Ujwary-Gil 2010, p. 70]:

- a tool of monitoring the implementation of knowledge management in an institution (it allows to specify the organization needs with regard to availability of knowledge, to assess the flow of knowledge, to specify a knowledge gap and whether the knowledge resources are properly used by employees in business processes),

- a planning document contributing to the development of knowledge management strategies (it explains which knowledge management strategy should be prepared).

Thus, a knowledge audit is both qualitative and analytical. Qualitative because it remains focused on people and the relationships between them (it focuses on behaviour of people associated with sharing knowledge, the creation of knowledge and its use), Analytical - it determines the key intangible assets and creates "maps" of knowledge by making an inventory of its sources and types and determines the methods of knowledge transfer in the organization, determines ways for knowledge measurement, diagnoses barriers/blockades of knowledge and diagnoses the type and scope of corrective/improving activities [Ujwary-Gil 2010, p. 73-74]. As the object of the audit Ujwary-Gill [2011, p. 13] acknowledges the employees, managerial personnel, customers and suppliers associated with the organization, while the key areas of conducting the knowledge audit include:

\footnotetext{
${ }^{1}$ It is also necessary to bear in mind that the manner of defining knowledge determines the way of knowledge management interpretation and the solutions which are adopted as part of the knowledge management.
} 
Table 2. Proposed ranges of the knowledge audit checklist

\begin{tabular}{|c|c|c|c|c|}
\hline $\begin{array}{l}\text { Organizational structure } \\
\text { of the organization } \\
\text { /organizational layer/ }\end{array}$ & $\begin{array}{l}\text { Knowledge resources } \\
\text { /content layer/ }\end{array}$ & $\begin{array}{l}\text { Communicational } \\
\text { employee behavior } \\
\text { /behavioral aspect/ }\end{array}$ & $\begin{array}{l}\text { Knowledge processes } \\
\text { /operating layer/ }\end{array}$ & $\begin{array}{l}\text { IT systems } \\
\text { /technical layer/ }\end{array}$ \\
\hline $\begin{array}{l}\text { - Identification of the } \\
\text { beneficiaries of } \\
\text { knowledge } \\
\text { (Who is the user of } \\
\text { knowledge? Who needs to } \\
\text { know about what?) } \\
\text { - Identification of the } \\
\text { supplier of knowledge } \\
\text { - System of granting of } \\
\text { access to knowledge } \\
\text { - System of access to } \\
\text { knowledge (In which way } \\
\text { is knowledge to be made } \\
\text { accessible?) } \\
\text { - System of knowledge } \\
\text { acquisition } \\
\text { - System of protecting } \\
\text { knowledge }\end{array}$ & $\begin{array}{l}\text { - Resources of knowledge } \\
\text { (What knowledge do we } \\
\text { currently have? What } \\
\text { knowledge resources are } \\
\text { currently in use? What } \\
\text { resources are needed?) } \\
\text { - Identify the silence } \\
\text { knowledge } \\
\text { (To what extent does the } \\
\text { knowledge resource } \\
\text { relate to hidden } \\
\text { knowledge?) } \\
\text { - Localization of resource } \\
\text { of knowledge } \\
\text { (Where are the resources } \\
\text { located? Where are the } \\
\text { right sources for the } \\
\text { resources of knowledge } \\
\text { we need? Who can } \\
\text { provide knowledge?) }\end{array}$ & $\begin{array}{l}\text { - Communicational } \\
\text { behaviour related } \\
\text { with using } \\
\text { knowledge (How do } \\
\text { employees currently } \\
\text { use resources of } \\
\text { knowledge we have } \\
\text { currently?) } \\
\text { - Communicational } \\
\text { behaviour related } \\
\text { with sharing } \\
\text { knowledge (How do } \\
\text { employees currently } \\
\text { share the knowledge } \\
\text { between each other? } \\
\text { /compare: table 1/) }\end{array}$ & $\begin{array}{l}\text { - Classifying } \\
\text { knowledge } \\
\text { (extracting areas, } \\
\text { issues, problems, } \\
\text { questions) } \\
\text { - Forms of } \\
\text { transmission / } \\
\text { codification / } \\
\text { archiving / storage / } \\
\text { verification / } \\
\text { acquisition / updating } \\
\text { of knowledge } \\
\text { - Bottlenecks (How } \\
\text { easy is it to find out } \\
\text { what we know? } \\
\text { Where are knowledge } \\
\text { flows impeded? How } \\
\text { can knowledge be } \\
\text { better shared and } \\
\text { organized?) }\end{array}$ & $\begin{array}{l}\text { - Databases and } \\
\text { information } \\
\text { processing systems } \\
\text { - Documentation } \\
\text { of accessing } \\
\text { knowledge }\end{array}$ \\
\hline
\end{tabular}

Source: own study.

- organizational structure of the organization,

- information structure,

- communication,

- changes in employee behaviour,

- knowledge processes,

- business processes,

- IT systems.

Conducting an audit in these areas is to enable the analysis and assessment of organizational knowledge from the point of view of its usability. The research methods possible to be used in the knowledge audit should include [Tiwana 1999, p. 220; Gourova, Antonova, Todorova 2009, p. 609; Mertins, Heisig, Ulbrich 2003, pp. 47-51]:

- survey questionnaire,

- interview questionnaire,

- analysis of bottlenecks in the flow of knowledge,

- Delphi method,

- focus group,

- participating,

- observation,

- story-telling techniques,

- rankings of documents/experts/websites,

- process documentation,

- analysis of social networks

- KMAT (The Knowledge Management Assessment Tool),
- KMD (Knowledge Management Diagnostic),

- KMMM (The KM Maturity Model).

The proposed ranges of the knowledge audit checklist are presented in Table 2.

\section{Conclusions}

Due to the existing restrictions with regard to the volume of text, the study is limited to a description of the essence of a communication audit and knowledge management audit, an indication of the objectives possible to be executed within these two audit types and determining the methods/tools which may be used therein. Both characterized types of audit, by allowing a diagnosis and assessment of the current condition of communication and knowledge management, create the possibility not only for monitoring, but also for improving the systems relating to those dimensions $^{2}$. It is worth noting that, due to the scope of the analysis, a communication audit can constitute a part of a knowledge audit. In the case of both of these audits, particular importance can be assigned to the use of tools such as a survey questionnaire and interview questionnaire. However, unquestionably current and important problem is still the issue of preparing questions for these questionnaires as well

${ }^{2}$ Both (communication audit and knowledge audit) should pinpoint the strengths and weaknesses in current communication and knowledge management processes. They should also indicate critical knowledge and information needed for the future. 
as the preparation of the methodology for these two audit types. In the context of the above considerations it should be considered particularly important to ask two questions during conducting an audit in these areas [Materska 2011]:

1. How is it?

and

\section{How should it be?}

In the case of diagnosis of the current state one should identify:

- What do we currently know?

- What resources do we currently have?

- How do employees currently use them?

On the other hand, identifying the desired states needs answering the following questions:

- What do we want to achieve?

- What should an organization know about to successfully achieve its goals?

- What resources are needed to ensure that the actions planned will achieve the desired effects?

- How should employees in the organization and outside the organization cooperate in this area?

In relation to the considered audits we should consider in what way it will be the best to evaluate the areas like knowledge resources, communication and knowledge processes, IT systems and employee behavior.

\section{Bibliography}

Audyt komunikacji wewnętrznej w oparciu o metodę SNA, 2009, materiał wewnętrzny, Episteme Manager, Warszawa.

Głuszek E., 2004, Zarzadzanie zasobami niematerialnymi przedsiębiorstwa, Wydawnictwo Akademii Ekonomicznej we Wrocławiu, Wrocław.

Gourova E., Antonova A., Todorova Y., 2009, Knowledge audit concepts, processes and practice, WSEAS Transactions on Business and Economics, no 6(12).

Grabosz J., 2014, Audyt komunikacji wewnętrznej w przedsiębiorstwie: propozycja narzędzia diagnostycznego, [in:] Zarzadzanie informacyjnym środowiskiem pracy, eds B.A. Basińska, I. Garnik, Wydział Zarządzania i Ekonomii Politechniki Gdańskiej, Gdańsk.

Hall R., 1992, The strategic analysis of intangible resources, Strategic Management Journal, no 13.

Hargie O., Tourish D., 2009, Auditing Organizational Communication, Routledge, London-New York.

Matejun M., Motyka A., 2016, Zasobowe zdolności dynamiczne w zarzadzaniu rozwojem firm sektora MSP, Monografie Politechniki Łódzkiej, tom 2199, Wydawnictwo Politechniki Łódzkiej, Łódź.
Materska K., 2011, Audyt informacji - problemy metodologiczne, E-mentor, no 5(42), http://www.e-mentor.edu.pl/artykul/ index/numer/42/id/888 (dostęp: 08.05.2018).

Mertins K., Heisig P., Ulbrich Ch., 2003, The Fraunhofer Knowledge Management Audit (FKM-Audit), [in:] Knowledge Management: Concepts and Best Practices, ed. K. Mertins, P. Heisig, J. Vorbeck, Springer, Berlin-Heidelberg-New York.

Mertins K., Heisig P., Vorbeck J., 2013, Knowledge Management: Concepts and Best Practices, Springer Science \& Business Media, Berlin-Heidelberg.

Mikuła B., Pietruszka-Ortyl A., 2010, Studium niematerialnych zasobów organizacji, Zeszyty Naukowe Uniwersytetu Ekonomicznego w Krakowie, Kraków, no 820.

Milewska-Zawada A., 2016, Audyt wewnętrzny szansa na sukces przedsiębiorstwa, Zeszyty Naukowe PWSZ w Płocku. Nauki Ekonomiczne, no 1(23), Płock.

Pietruszka-Ortyl A., 2010, Model doboru kooperanta ze względu na jego zasoby niematerialne, Zeszyty Naukowe Uniwersytetu Ekonomicznego w Krakowie, no 820, Kraków.

Quinn D., Hargie O., 2004, Internal communication audits: a case study, Corporate Communications: An International Journal, no 9(2).

Rokita J., 2005, Zarzadzanie strategiczne. Tworzenie i utrzymywanie przewagi konkurencyjnej, PWE, Warszawa.

Shelby A.N., Reinsch N.L., 1996, The communication audit: a framework for teaching management communication, Business Communication Quarterly, no 59(2).

Skowron Ł., 2013, Istota i pomiar niematerialnych zasobów przedsiębiorstwa, Humanities and Social Sciences, no 20(2).

Tiwana A., 1999, Knowledge Management Toolkit, Prentice Hall PTR, Michigan.

Tourish D., Hargie O., 2000, Auditing Communication to Maximise Performance, [in:] Handbook of Communication Audits for Organizations, ed. O. Hargie i D. Tourish, Routledge, New York.

Ujwary-Gil A., 2010, Wybrane elementy i obszary audytu wiedzy przedsiębiorstwa, [in:] Organizacje komercyjne i niekomercyjne wobec wzmożonej konkurencji oraz wzrastajacych wymagań konsumentów, eds A. Nalepka i A. Ujwary-Gil, Wyższa Szkoła Biznesu-National-Louis University w Nowym Sączu, Nowy Sącz.

Ujwary-Gil A., 2011, Audyt wiedzy przedsiębiorstwa, Przegląd Organizacji, no 2.

Urbanek G., 2011, Kompetencje a wartość przedsiębiorstwa: Zasoby niematerialne $w$ nowej gospodarce, Wolters Kluwer Polska, Warszawa.

Wilczewski M., 2014, Audyt komunikacyjny w badaniu efektywności procesu komunikacji wewnętrznej przedsiębiorstw, Studia i Materiały, no 17.

Winkler R., 2010, Audyt komunikacyjny - wymiar wewnętrzny, [w:] Systemy controlingu, monitoringu i audytu, eds A. Stabryła, Mfiles.pl, Kraków.

Winkler R., 2015, Techniki komunikacji w procesach zmian, Nauki o Zarządzaniu. Management Sciences, no 2(23). 


\section{AUDYT KOMUNIKACYJNY I AUDYT ZARZĄDZANIA WIEDZA JAKO PRZYKLADY AUDYTU ZASOBÓW NIEMATERIALNYCH ORGANIZACJI}

Streszczenie: Wraz z rozwojem Internetu i technologii informatycznych, poszerzaniem zakresu praw własności intelektualnej i pojawieniem się efektu dźwigni intelektualnej w zakresie wykorzystania wiedzy w przygotowywaniu innowacyjnych produktów i usług można zaobserwować wzrost znaczenia wartości niematerialnych i prawnych w budowaniu przewagi strategicznej podmiotów gospodarczych. Ważne jest to, że skuteczne zarządzanie organizacją wymaga umiejętnego korzystania z informacji odzwierciedlających funkcjonowanie wszystkich podsystemów danej instytucji, w tym systemów funkcjonalnych (takich jak system komunikacji i system zarządzania wiedzą klasyfikowany jako wartości niematerialne). Taką wiedzę zapewnia audyt wewnętrzny będący narzędziem obejmującym niezależną i obiektywną analizę skuteczności i wydajności procesów, wykorzystywaną przede wszystkim do usprawnienia tych procesów. Celem niniejszego opracowania jest przedstawienie możliwości wykorzystania audytu w praktyce biznesowej w zakresie zarządzania wartością niematerialną w odniesieniu do systemu komunikacji i systemu zarządzania wiedzą.

Słowa kluczowe: audit, zasoby niematerialne, komunikacja, zarządzanie wiedzą. 